Louisiana State University

LSU Digital Commons

7-1-2007

\title{
Unidirectional $\mathrm{Na}^{+}$and $\mathrm{Ca}^{2+}$ fluxes in two euryhaline teleost fishes, Fundulus heteroclitus and Oncorhynchus mykiss, acutely submitted to a progressive salinity increase
}

\author{
Viviane Prodocimo \\ Universidade Tecnologica Federal do Parana \\ Fernando Galvez \\ McMaster University \\ Carolina A. Freire \\ Universidade Tecnologica Federal do Parana \\ Chris M. Wood \\ McMaster University
}

Follow this and additional works at: https://digitalcommons.Isu.edu/biosci_pubs

\section{Recommended Citation}

Prodocimo, V., Galvez, F., Freire, C., \& Wood, C. (2007). Unidirectional $\mathrm{Na}^{+}$and $\mathrm{Ca}^{2+}$ fluxes in two euryhaline teleost fishes, Fundulus heteroclitus and Oncorhynchus mykiss, acutely submitted to a progressive salinity increase. Journal of Comparative Physiology B: Biochemical, Systemic, and Environmental Physiology, 177 (5), 519-528. https://doi.org/10.1007/s00360-007-0150-y

This Article is brought to you for free and open access by the Department of Biological Sciences at LSU Digital Commons. It has been accepted for inclusion in Faculty Publications by an authorized administrator of LSU Digital Commons. For more information, please contact ir@lsu.edu. 


\title{
Unidirectional $\mathrm{Na}^{+}$and $\mathrm{Ca}^{2+}$ fluxes in two euryhaline teleost fishes, Fundulus heteroclitus and Oncorhynchus mykiss, acutely submitted to a progressive salinity increase
}

\author{
Viviane Prodocimo $\cdot$ Fernando Galvez \\ Carolina A. Freire • Chris M. Wood
}

Received: 15 September 2006 / Revised: 30 January 2007 / Accepted: 30 January 2007 / Published online: 22 February 2007

(C) Springer-Verlag 2007

\begin{abstract}
Na}^{+}$and $\mathrm{Ca}^{2+}$ regulation were compared in two euryhaline species, killifish (normally estuarineresident) and rainbow trout (normally freshwater-resident) during an incremental salinity increase. Wholebody unidirectional fluxes of $\mathrm{Na}^{+}$and $\mathrm{Ca}^{2+}$, whole body $\mathrm{Na}^{+}$and $\mathrm{Ca}^{2+}$, and plasma concentrations (trout only), were measured over 1-h periods throughout a total 6-h protocol of increasing salinity meant to simulate a natural tidal flow. Killifish exhibited significant increases in both $\mathrm{Na}^{+}$influx and efflux rates, with efflux slightly lagging behind efflux up to $60 \% \mathrm{SW}$, but net $\mathrm{Na}^{+}$balance was restored by the time killifish reached $100 \%$ SW. Whole body $\mathrm{Na}^{+}$did not change, in agreement with the capacity of this species to tolerate daily salinity fluctuations in its natural habitat. In contrast,
\end{abstract}

Communicated by G. Heldmaier.

V. Prodocimo $(\bowtie) \cdot$ C. A. Freire

Departamento de Fisiologia,

Setor de Ciências Biológicas, Universidade

Federal do Paraná, Centro Politécnico, Curitiba,

Paraná 81531-990, Brazil

e-mail: vprodocimo@yahoo.com.br

F. Galvez $\cdot$ C. M. Wood

Department of Biology,

McMaster University, 1280 Main Street West,

Hamilton, ON L8S 4K1Canada

F. Galvez

Department of Biological Sciences,

Louisiana State University, 216 Life Sciences Building,

Baton Rouge, LA 70803, USA

\section{M. Wood}

Department of Marine Biology and Fisheries,

Rosenstiel School of Marine and Atmospheric

Sciences, University of Miami, Miami, FL 33149, USA rainbow trout experienced a dramatic increase in $\mathrm{Na}^{+}$ influx (50-fold relative to $\mathrm{FW}$ values), but not $\mathrm{Na}^{+}$ efflux between 40 and $60 \% \mathrm{SW}$, resulting in a large net loading of $\mathrm{Na}^{+}$at higher salinities $(60-100 \%$ SW), and increases in plasma $\mathrm{Na}^{+}$and whole body $\mathrm{Na}^{+}$at $100 \%$ $\mathrm{SW}$. Killifish were in negative $\mathrm{Ca}^{2+}$ balance at all salinities, whereas trout were in positive $\mathrm{Ca}^{2+}$ balance throughout. $\mathrm{Ca}^{2+}$ influx rate increased two- to threefold in killifish at 80 and $100 \% \mathrm{SW}$, but there were no concomitant changes in $\mathrm{Ca}^{2+}$ efflux. $\mathrm{Ca}^{2+}$ flux rates were affected to a larger degree in trout, with twofold increases in $\mathrm{Ca}^{2+}$ influx at $40 \% \mathrm{SW}$ and sevenfold increases at $100 \%$ SW. Again, there was no change in $\mathrm{Ca}^{2+}$ efflux with salinity, so plasma $\mathrm{Ca}^{2+}$ concentration increased in $100 \%$ SW. As the killifish is regularly submitted to increased salinity in its natural environment, it is able to rapidly activate changes in unidirectional fluxes in order to ensure ionic homeostasis, in contrast to the trout.

Keywords Calcium · Ion fluxes · Killifish · Rainbow trout $\cdot$ Salinity $\cdot$ Sodium

\section{Introduction}

Marine teleosts are strongly hypotonic to seawater, resulting in a tendency for solutes to move passively into the animal. In contrast, freshwater teleosts tend to lose ions to the hypotonic aquatic environment (reviews in Jobling 1995; Evans et al. 1999, 2005; Marshall 2003; Kirschner 2004; Marshall and Grosell 2005). Many teleosts are extremely euryhaline, displaying great capacity to tolerate and adapt to wide variations in salinity, reducing and even reversing net fluxes of 
ions through their surface epithelia (Potts and Evans 1967; Bath and Eddy 1979a, b; Perry and Flik 1988; Wood and Marshall 1994; Goss et al. 1998; Marshall 2003; Wood and Laurent 2003).

Two such teleosts are the killifish Fundulus heteroclitus (Family Cyprinodontidae) and the rainbow trout Oncorhynchus mykiss (Family Salmonidae). Fundulus heteroclitus is normally resident in the intermediate salinities of estuaries and salt marshes and is extremely euryhaline, being exposed to daily salinity changes throughout the tidal cycle. This species also tolerates abrupt changes of water salinity between 0 and $120 \%$ (Griffith 1974) and has been a preferred model for the study of euryhalinity in teleost fish (e.g., Jacob and Taylor 1983; Marshall et al. 1999, 2000; Daborn et al. 2001; Katoh et al. 2003; Marshall 2003; Wood and Laurent 2003). Oncorhynchus mykiss is normally resident in freshwater, but may enter brackish and marine waters to feed, and some strains go to sea for prolonged periods (Sedgewick 1982). This species is also considered to be very euryhaline, and has been a common model used in euryhalinity studies (e.g., Gordon 1959, 1963; Bath and Eddy 1979a, b; Eddy and Bath 1979; Richards et al. 2003; Hawkings et al. 2004).

A direct positive relationship between unidirectional $\mathrm{Na}^{+}$(and $\mathrm{Cl}^{-}$) fluxes and salinity has already been demonstrated for the killifish $F$. heteroclitus exposed to different salinities for few hours $(\sim 3-4 \mathrm{~h})$ up to several days or weeks of exposure/acclimation (Motais et al. 1966; Potts and Evans 1967; Pic 1978; Wood and Marshall 1994; Wood and Laurent 2003). Studies have also been conducted with the rainbow trout $O$. mykiss, mostly employing 7 or more days of acclimation to different salinities (Gordon 1963; Bath and Eddy 1979a; Eddy and Bath 1979; Perry and Laurent 1989), and have also shown increased fluxes associated with greater salinity. Unidirectional $\mathrm{Ca}^{2+}$ flux measurements in F. heteroclitus (Mayer-Gostan et al. 1983) and O. mykiss (Perry and Flik 1988) are fairly rare; to our knowledge, they have never been determined while imposing salinity changes for these species.

However, at present, there is almost no information on what happens when euryhaline fish experience fairly rapid and progressive salinity changes, as might happen during a tidal cycle in an estuary or salt marsh, or during migration through these environments. The goal of the present study was to fill the gap in the literature, determining unidirectional fluxes of $\mathrm{Na}^{+}$and $\mathrm{Ca}^{2+}$ in the whole fish (killifish and rainbow trout) during a progressive increase in salinity by small step changes over $6 \mathrm{~h}$, simulating the challenges imposed by the tidal cycle in an estuarine environment. The results have been analyzed comparatively between trout and killifish, under the hypothesis that a euryhaline freshwater species and a euryhaline estuarine resident species would display different patterns of ion flux modulation when faced with the same stress of rapid salinity increase.

\section{Materials and methods}

Animals

Adult specimens of $F$. heteroclitus (northern race, sometimes classified as the sub-species macrolepidotus; mean weight $=2.7 \pm 0.08 \mathrm{~g}$ ) were obtained from the estuaries of Antigonish, NS, Canada, and Hampton, NH, USA. Fish were air-shipped to McMaster University, Hamilton, ON, Canada, where they were maintained in 500-1 tanks of recirculated water with a salinity of $10 \%$ of full-strength seawater (SW) ( 3.5\%) for at least 2 weeks prior to experimentation. This water was made up using commercial sea salts (Instant Ocean $^{\mathrm{TM}}$, Aquarium Systems Inc., Mentor, OH, USA) appropriately diluted in Lake Ontario water (composition as shown below). Water was maintained at approximately $20^{\circ} \mathrm{C}$ with constant aeration. Fish were fed daily with fish food in flakes (Wardley Total Tropical Gourmet Flake Blend, Hartz Mountain Corp., Secausus, USA), and frozen brine shrimp (San Francisco Bay Brand, Newark, USA).

Adult rainbow trout (O. mykiss) (mean weight $=169.5 \pm 10.6 \mathrm{~g}$ ) were purchased from Humber Springs Trout Hatchery (Orangeville, ON, Canada), and taken to McMaster University, where they were held in 500-1 tanks supplied under flow-through conditions with moderately hard fresh water from Lake Ontario (in $\mathrm{mM}$ : $\mathrm{Ca}^{2+}=1.0, \mathrm{Mg}^{2+}=0.2, \mathrm{Na}^{+}=0.6$, $\left.\mathrm{Cl}^{-}=0.8, \mathrm{~K}^{+}=0.05 ; \mathrm{pH}=7.9-8.0\right)$. The fish were acclimated for at least 2 weeks prior to experimentation. Water temperature was maintained at $15^{\circ} \mathrm{C}$ under constant aeration. Trout were fed daily (ad libitum) with commercial trout chow (Martin Mills Inc., Canada).

Note that while the size of killifish and trout obviously differed, our goal was to compare adult animals of the two species. Also, the acclimation temperatures, $20^{\circ} \mathrm{C}$ for the killifish and $15^{\circ} \mathrm{C}$ for the trout, and salinities, 3.5\% (10\% seawater) for the killifish and $0 \%$ (freshwater) for the trout differed, reflecting their normal environments.

Determination of unidirectional sodium and calcium fluxes

Flux experiments were conducted using the radioisotopes ${ }^{22} \mathrm{Na}^{+}$(Perkin Elmer, Wellesley, MA, USA) or 
${ }^{24} \mathrm{Na}^{+}$(McMaster University Nuclear Reactor) and ${ }^{45} \mathrm{Ca}^{2+}$ (Perkin Elmer).

\section{Influx experiments}

Fish were submitted to a progressive, step-wise rise in salinity to simulate seawater entry in estuaries during tidal flow. All salinities were again made up with commercial sea salts (Instant Ocean ${ }^{\mathrm{TM}}$ ) diluted with Lake Ontario water. The measured ion compositions are shown in Table 1. Using a standard value of $\mathrm{Na}^{+}$for full strength seawater (470.2 mM/l; Barnes, 1954), the nominal and actual values were: $10 \%=15.6 \% \mathrm{SW}$, $20 \%=23.4 \%$ SW, $40 \%=43.2 \%$ SW, $60 \%=57.4 \%$ SW, $80 \%=75.5 \% \quad$ SW, $100 \%=93.4 \% \quad$ SW. For simplicity, nominal values are used throughout the text.

Fundulus heteroclitus and O. mykiss $(N=36$ each $)$ were transferred individually from their stock tanks to either 2-l aquaria containing water of salinity $10 \% \mathrm{SW}$ or 4-1 aquaria containing $\mathrm{FW}$, respectively. These water volumes were used during the radioisotopic flux determinations. Unidirectional ${ }^{24} \mathrm{Na}^{+}$and ${ }^{45} \mathrm{Ca}^{2+}$ influxes were determined from the accumulation of the radioactively-labeled isotope in fish. The experimental regime involved exposing fish at an initial salinity of FW for O. mykiss or $10 \% \mathrm{SW}$ for $F$. heteroclitus for $1 \mathrm{~h}$, and increasing them incrementally to $20 \% \mathrm{SW}$, $40 \%$ SW, $60 \%$ SW, $80 \%$ SW and $100 \%$ SW, each for a successive $1 \mathrm{~h}$ period. Six fish per species were radioisotopically fluxed at each of the six salinities, after which they were terminated for analysis of ion influx as described below. The amounts of ${ }^{24} \mathrm{Na}^{+}$added to the water for the determination of $\mathrm{Na}^{+}$influx were: $24 \mu \mathrm{Ci}$ in the 10 -to- $60 \% \mathrm{SW}$ (for $F$. heteroclitus experiments) or FW-to-60\% SW (for O. mykiss experiments), $32 \mu \mathrm{Ci}$ in $80 \% \mathrm{SW}$, and $40 \mu \mathrm{Ci}$ in $100 \% \mathrm{SW}$. The amounts of ${ }^{45} \mathrm{Ca}^{2+}$ added to the water for the determination of $\mathrm{Ca}^{2+}$ influx were: $30 \mu \mathrm{Ci}$ in the 10 -to- $60 \% \mathrm{SW}$ (for F. heteroclitus experiments) or freshwater-to-60\%
SW (for O. mykiss experiments), $40 \mu \mathrm{Ci}$ in $80 \% \mathrm{SW}$, and $50 \mu \mathrm{Ci}$ in $100 \% \mathrm{SW}$. The increased amounts of radioactivity added to higher salinity waters kept specific activities between treatments as close as economically feasible. Water was sampled $(5 \mathrm{ml})$ at the start (time $0 \mathrm{~min}$ ) and after $30 \mathrm{~min}\left(\right.$ for ${ }^{24} \mathrm{Na}^{+}$), and $60 \mathrm{~min}$ (for ${ }^{45} \mathrm{Ca}^{2+}$ ) for each salinity. Water samples for ${ }^{24} \mathrm{Na}^{+}$ detection were placed in $20 \mathrm{ml}$ polypropylene tubes, whereas those sampled for ${ }^{45} \mathrm{Ca}^{2+}$ were stored in $20 \mathrm{ml}$ glass vials. Immediately following water sampling, fish were transferred to non-radioactive water (of the same salinity) for $5 \mathrm{~min}$ in order to remove any radioactivity adsorbed to the external surface of the fish, then terminally anesthetized in $0.5 \mathrm{~g} / \mathrm{l}$ MS-222, weighed, and sampled by caudal puncture for blood (O. mykiss only).

Due to the short half-life of ${ }^{24} \mathrm{Na}^{+}$, it was possible to monitor the unidirectional influx of $\mathrm{Na}^{+}$and $\mathrm{Ca}^{2+}$ influx simultaneously in the same fish. Whole body uptake of ${ }^{24} \mathrm{Na}^{+}$in killifish was measured immediately after fluxing by sacrificing the fish as outlined above, then placing the whole animals in 20-ml polypropylene scintillation vials and measuring gamma radiation using a Minaxi Autogamma 5000 counter (Perkin Elmer). Following gamma detection, animals were transferred to $50 \mathrm{ml}$ conical tubes where they were digested in four volumes of $1 \mathrm{~N} \mathrm{HNO}_{3}$ and warmed to $60^{\circ} \mathrm{C}$ for $24 \mathrm{~h}$. Trout, due to their large size, were homogenized in a blender with one volume of water. Three sub-samples of each homogenate were sampled and promptly analyzed for whole-body ${ }^{24} \mathrm{Na}^{+}$. Water samples for ${ }^{24} \mathrm{Na}^{+}$analysis were measured alongside the tissue samples, with the gamma detector set for half-life decay correction. Water samples were diluted for analysis of total $\mathrm{Na}^{+}$and $\mathrm{Ca}^{2+}$ by flame atomic absorption spectroscopy. Analysis of ${ }^{45} \mathrm{Ca}^{2+}$ was performed after 7 days, which represented approximately 10 half-lives for ${ }^{24} \mathrm{Na}^{+}$, thus avoiding interference from ${ }^{24} \mathrm{Na}^{+}$emission when subjecting the samples to liquid scintillation counting. Following gamma detection,

Table 1 Ion concentrations ( $\mathrm{mmol} / \mathrm{l})$ in the waters used in the flux experiments

\begin{tabular}{lcrr}
\hline Water & $\mathrm{Na}^{+}$ & $\mathrm{Cl}^{-}$ & $\mathrm{Ca}^{2+}$ \\
\hline FW & $0.7 \pm 0.1(n=6)$ & $1.1 \pm 0.1(n=7)$ & $0.9 \pm 0.1(n=4)$ \\
$10 \%$ SW & $73.3 \pm 4.8(n=5)$ & $104.3 \pm 14.0(n=5)$ & $2.3 \pm 0.1(n=4)$ \\
$20 \%$ SW & $109.9 \pm 8.3(n=9)$ & $133.4 \pm 8.5(n=7)$ & $3.4 \pm .0 .2(n=4)$ \\
$40 \%$ SW & $203.1 \pm 12.1(n=10)$ & $212.0 \pm 11.1(n=7)$ & $4.9 \pm 0.3(n=4)$ \\
$60 \%$ SW & $270.1 \pm 11.5(n=9)$ & $303.2 \pm 5.9(n=7)$ & $6.0 \pm 0.3(n=4)$ \\
$80 \%$ SW & $354.8 \pm 13.1(n=9)$ & $412.6 \pm 7.9(n=7)$ & $7.9 \pm 0.4(n=4)$ \\
$100 \%$ SW & $439.1 \pm 12.9(n=10)$ & $534.6 \pm 7.2(n=7)$ & $9.7 \pm 0.5(n=4)$ \\
\hline
\end{tabular}

Values are represented as the mean \pm the standard error of the mean; $n$ is the number of water samples measured at each salinity. FW was used as the starting salinity for rainbow trout only, whereas $10 \% \mathrm{SW}$ was used as the initial salinity for experiments on killifish $S W$ Seawater; $F W$ fresh water 
homogenates were digested immediately as described above for the killifish. For both killifish and trout, digests were centrifuged at $600 \mathrm{~g}$ for $10 \mathrm{~min}$. Five milliliters of the supernatant were added to $10 \mathrm{ml}$ of UltimaGold AB (Perkin Elmer, USA), a scintillation cocktail with a high capacity for mineral acids. All samples were counted for ${ }^{45} \mathrm{Ca}^{2+}$ using a liquid scintillation counter (Tri-Carb 2900TR, Perkin Elmer, USA). Ten milliliters of ACS (Aqueous Counting Scintillant; Amersham Biosciences, Little Chalfont, UK) were added to water samples set aside for ${ }^{45} \mathrm{Ca}^{2+}$ analysis and measured alongside the tissue samples. Both tissues and water samples were quench-corrected using corresponding curves obtained by the tSIE method (Transformed Spectral Index of the External Standard; L'Annunziata 2003). An additional correction factor was used to account for differential counting efficiencies between Ultima Gold and ACS.

For both species, the remaining supernatant, as well as blood plasma for trout only, was used for the determination of total $\mathrm{Na}^{+}$and $\mathrm{Ca}^{2+}$ concentrations. Analyses were performed using an atomic absorption spectrophotometer (Varian SpectraAA 220FS, Mulgrave, Australia) against certified standards (Fisher Scientific, Toronto, ON, Canada), according to the manufacturer's instructions.

Influx rates (measured during $1 \mathrm{~h}$ ), expressed in $\mu \mathrm{mol} / \mathrm{kg} / \mathrm{h}$, were calculated using the total radioactivity reading of each fish for ${ }^{24} \mathrm{Na}^{+}$(counts per minute; cpm) or ${ }^{45} \mathrm{Ca}^{2+}$ (disintegrations per minute; $\mathrm{dpm}$ ). These values were divided by the measured specific activity ( $\mathrm{cpm} / \mu \mathrm{mol}$ for ${ }^{24} \mathrm{Na}^{+}$or $\mathrm{dpm} / \mu \mathrm{mol}$ for ${ }^{45} \mathrm{Ca}^{2+}$ ) for each salinity, divided by the weight of the fish $(\mathrm{g})$, and multiplied by 1,000 to convert the weight unit to $\mathrm{kg}$.

\section{Efflux experiments}

Efflux rate was determined as the rate of loss of radioisotopes from the fish to the water. Due to the unavailability of ${ }^{24} \mathrm{Na}^{+}$at the time of these experiments, ${ }^{22} \mathrm{Na}^{+}$ was used as a substitute. However, this meant that it was necessary to perform ${ }^{22} \mathrm{Na}^{+}$and ${ }^{45} \mathrm{Ca}^{2+}$ efflux determinations on separate sets of animals. ${ }^{22} \mathrm{Na}^{+}$and ${ }^{45} \mathrm{Ca}^{2+}$ were diluted in Cortland saline (Wolf 1963) and administered to the fish by intraperitoneal injection $(1 \mu \mathrm{l} / \mathrm{g}$ of fish) using a Hamilton syringe. After killifish were injected with $0.05 \mu \mathrm{Ci} / \mathrm{g}$ of ${ }^{22} \mathrm{Na}^{+}(n=5$ for $10 \% \mathrm{SW}$, $n=10$ for $20-100 \% \mathrm{SW})$ or $1.0 \mu \mathrm{Ci} / \mathrm{g}$ of ${ }^{45} \mathrm{Ca}^{2+}(n=6)$, they were placed in individual aquaria containing $250 \mathrm{ml}$ of $10 \% \mathrm{SW}$. Trout received $0.05 \mu \mathrm{Ci} / \mathrm{g}$ of ${ }^{22} \mathrm{Na}^{+}$ $(n=6)$, and $0.2 \mu \mathrm{Ci} / \mathrm{g}$ of ${ }^{45} \mathrm{Ca}^{2+}(n=6)$, and placed in individual aquaria containing 31 of fresh water. Radioactivity was allowed to equilibrate in the animals for
$4 \mathrm{~h}$ during which time water samples were taken at 1-h intervals to account for radioisotope losses during this initial equilibration period.

At the start of the efflux period, fish were individually transferred to aquaria of increasing salinities, exactly as already described for the influx experiments. Water was sampled at time zero, and after 15 , 30,45 , and $60 \mathrm{~min}$, to calculate the loss rate of radioactivity to the water over time. These efflux rates could only be calculated after estimates were made of the average internal specific activities at each salinity, although the method used to obtain these values varied between species. For measurements of ${ }^{22} \mathrm{Na}^{+}$and ${ }^{45} \mathrm{Ca}^{2+}$ efflux for trout, and ${ }^{45} \mathrm{Ca}^{2+}$ efflux for killifish, estimates were required for ion space. These values were obtained by determining the volumes needed to account for the entire injected quantities of radioisotopes, assuming the entire ion spaces were homogenous and did not vary with salinity. These ion spaces were multiplied by the plasma $\mathrm{cpm} / \mathrm{ml}$ values to obtain total radioisotopic burdens at the end of the $100 \% \mathrm{SW}$ exposures. Once these total $\mathrm{cpm} /$ fish were calculated, estimates of $\mathrm{cpm} / \mathrm{fish}$ at the lower salinities were achieved by sequentially adding the radioactivity lost to the water at each lower salinity interval back to the fish. Finally, specific activities were calculated by taking these $\mathrm{cpm} /$ fish (at each salinity) and dividing by the original ion spaces (in ml per fish), and further dividing by the plasma ion concentrations. According to this methodology, $\mathrm{Na}^{+}$space for trout remained constant between 37 and $41 \%$ in fish at weights of $178 \mathrm{~g}$ and above, but were greater in smaller fish $(75 \%$ in a trout weighing only $83 \mathrm{~g}$ ). $\mathrm{Ca}^{2+}$ spaces for trout and killifish were estimated at $39.3 \pm 2.6$ and $62.0 \pm 4.5 \%$, respectively, and did not vary appreciably with size. Calculation of specific activities used to analyze ${ }^{22} \mathrm{Na}^{+}$ efflux rates for killifish did not necessitate analysis of $\mathrm{Na}^{+}$space since total cpm/fish (at the end of the $100 \%$ SW exposure) could be directly analyzed. Using these terminal ${ }^{22} \mathrm{Na}^{+}$burdens in whole-bodies, radioactivity in fish $(\mathrm{cpm} / \mathrm{fish})$ at each salinity were calculated by adding back to the fish that ${ }^{22} \mathrm{Na}^{+}$lost to the water during the course of the exposures. Finally, specific activities were calculated by taking these $\mathrm{cpm} /$ fish data and dividing them by the terminal whole-body $\mathrm{Na}^{+}$ concentrations ( $\mu \mathrm{mol} /$ fish).

Efflux rates expressed in $\mu \mathrm{mol} / \mathrm{kg} / \mathrm{h}$ were calculated by linear regression of $\mathrm{cpm} / \mathrm{ml}$ radioactivity appearing in the water over time, and by dividing these rates by specific activity and fish weights. The net flux rates of ions were calculated as the difference between independently determined values of influx and efflux rates, using random pairing of individuals. 
Statistical analysis

Data have been presented as mean \pm standard error of the mean. Statistical comparisons of increasing salinity (FW, 10, 20, 40, 60, 80 and 100\% SW) were made for each variable (influx rate, efflux rate, plasma and whole body $\mathrm{Na}^{+}$and $\mathrm{Ca}^{2+}$ concentrations) using a one-way ANOVA, followed by the post hoc test of Tukey, with $P$ set at 0.05 . The one-sample $t$ test was used to test whether net fluxes were significantly different from zero, in either direction (i.e., two-tailed).

\section{Results}

\section{Unidirectional sodium fluxes}

In $F$. heteroclitus, $\mathrm{Na}^{+}$influx and efflux rates $(\sim 4,000 \mu \mathrm{mol} / \mathrm{kg} / \mathrm{h})$, were in approximate balance at the acclimation salinity of $10 \%$ SW. Increasing salinity incrementally from 10 to $100 \%$ SW caused progressive increases in both $\mathrm{Na}^{+}$influx and $\mathrm{Na}^{+}$efflux rates, with the increase in efflux lagging slightly behind the increase in influx (Fig. 1a). The increase in influx became statistically significant at $60 \% \mathrm{SW}$, with a rate approximately 2.5 -fold above those measured in controls at $10 \% \mathrm{SW}$. Influx rates remained stable at salinities higher than $60 \% \mathrm{SW}$. The increase in efflux was approximately twofold by $80 \% \mathrm{SW}$, where it first became statistically significant (at least relative to $20 \% \mathrm{SW}$ ), and was greater than threefold in $100 \% \mathrm{SW}$. There were no net fluxes (i.e., values were not significantly different from zero), except for a net loss of sodium in 100\% SW (Table 2). This stability in net fluxes was reflected by the whole body $\mathrm{Na}^{+}$concentrations, which did not vary significantly throughout the entire salinity regime (Fig. 1b).

In low salinities, $\mathrm{Na}^{+}$flux rates in trout were considerably smaller than those measured in killifish. Influx and efflux rates in the FW to which the trout were acclimated were in approximate balance. $\mathrm{Na}^{+}$influx rate in $\mathrm{FW}$ was around $600 \mu \mathrm{mol} / \mathrm{kg} / \mathrm{h}$ and rose significantly about fourfold in $20 \%$ SW and fivefold in $40 \%$ SW to about $3,250 \mu \mathrm{mol} / \mathrm{kg} / \mathrm{h}$. However, the most pronounced increase in influx occurred between 40 and $60 \% \mathrm{SW}$, when the rate rose an additional tenfold to about $33,000 \mu \mathrm{mol} / \mathrm{kg} / \mathrm{h}$, more than 50 -fold greater than in $\mathrm{FW}$ (Fig. 2a). Influx rate stayed at this high level at 80 and $100 \% \mathrm{SW}$, and was therefore about threefold greater than in killifish at these same salinities (Fig. 1a). In marked contrast, $\mathrm{Na}^{+}$efflux rate remained rather stable, showing only a slight but significant increase in the 80 and $100 \% \mathrm{SW}$-treated trout compared to the FWexposed fish (Fig. 2a). Due to the disproportionately
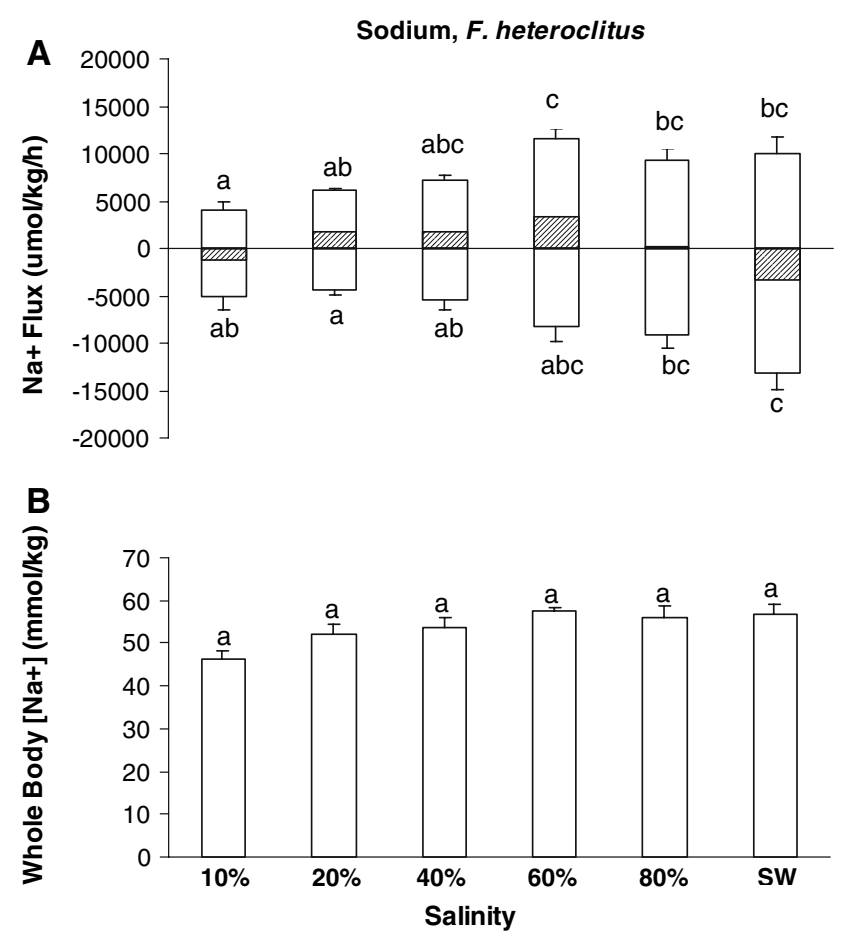

Fig. 1 a $\mathrm{Na}^{+}$influx (upward bars) $(n=6)$ and efflux rates (downward bars) $(n=5$ for $10 \%$ SW, $n=10$ for $20-100 \%$ SW) (mean $\pm \mathrm{SEM}, \mu \mathrm{mol} / \mathrm{kg} / \mathrm{h}$ ) in $F$. heteroclitus submitted to progressive increases in water salinity over 1 -h periods. The hatched bars represent the difference (net flux rates) between the mean influx (positive) and efflux (negative) rates. b Whole-body $\mathrm{Na}^{+}$ ( $n=6$ for $10-80 \%$ SW, $n=25$ for $100 \%$ SW) (mean \pm SEM, $\mathrm{mmol} / \mathrm{kg}$ ) in $F$. heteroclitus following radioisotopic fluxing at that particular salinity. Bars sharing a letter are not significantly different $(P<0.05)$

Table $2 \mathrm{Na}^{+}$and $\mathrm{Ca}^{2+}$ net fluxes $(\mu \mathrm{mol} / \mathrm{kg} / \mathrm{h})$ calculated as the difference between influx ( $n=6$ per salinity) and efflux $(n=5-6$ per salinity) rates measured from different batches of killifish and trout

\begin{tabular}{lcc}
\hline & $\mathrm{Na}^{+}$ & $\mathrm{Ca}^{2+}$ \\
\hline F. heteroclitus & & \\
$10 \%$ SW & $-1,373 \pm 740$ & $-171 \pm 37.5^{*}$ \\
$20 \%$ SW & $1,382 \pm 704$ & $-121 \pm 38.4^{*}$ \\
$40 \%$ SW & $591 \pm 1,645$ & $-109 \pm 48.6$ \\
$60 \%$ SW & $1,557 \pm 2,519$ & $-206 \pm 46.2^{*}$ \\
$80 \%$ SW & $-878 \pm 1,978$ & $-50.0 \pm 53.4$ \\
$100 \%$ SW & $-5,995 \pm 1,866^{*}$ & $-29.4 \pm 89.0$ \\
O. mykiss & & \\
FW & $-1,267 \pm 422^{*}$ & $15.9 \pm 3.66^{*}$ \\
$20 \%$ SW & $-96.9 \pm 507$ & $34.4 \pm 7.87^{*}$ \\
$40 \%$ SW & $577 \pm 416$ & $46.9 \pm 6.60^{*}$ \\
$60 \%$ SW & $30,477 \pm 3,227^{*}$ & $51.8 \pm 8.71^{*}$ \\
$80 \%$ SW & $21,285 \pm 2,755^{*}$ & $61.9 \pm 6.52^{*}$ \\
$100 \%$ SW & $22,556 \pm 5,368^{*}$ & $155.9 \pm 43.9^{*}$ \\
\hline
\end{tabular}

Values are expressed as the mean \pm standard error of the mean $S W$ Seawater; $F W$ freshwater

* Net flux significantly different $(P<0.05)$ from zero 

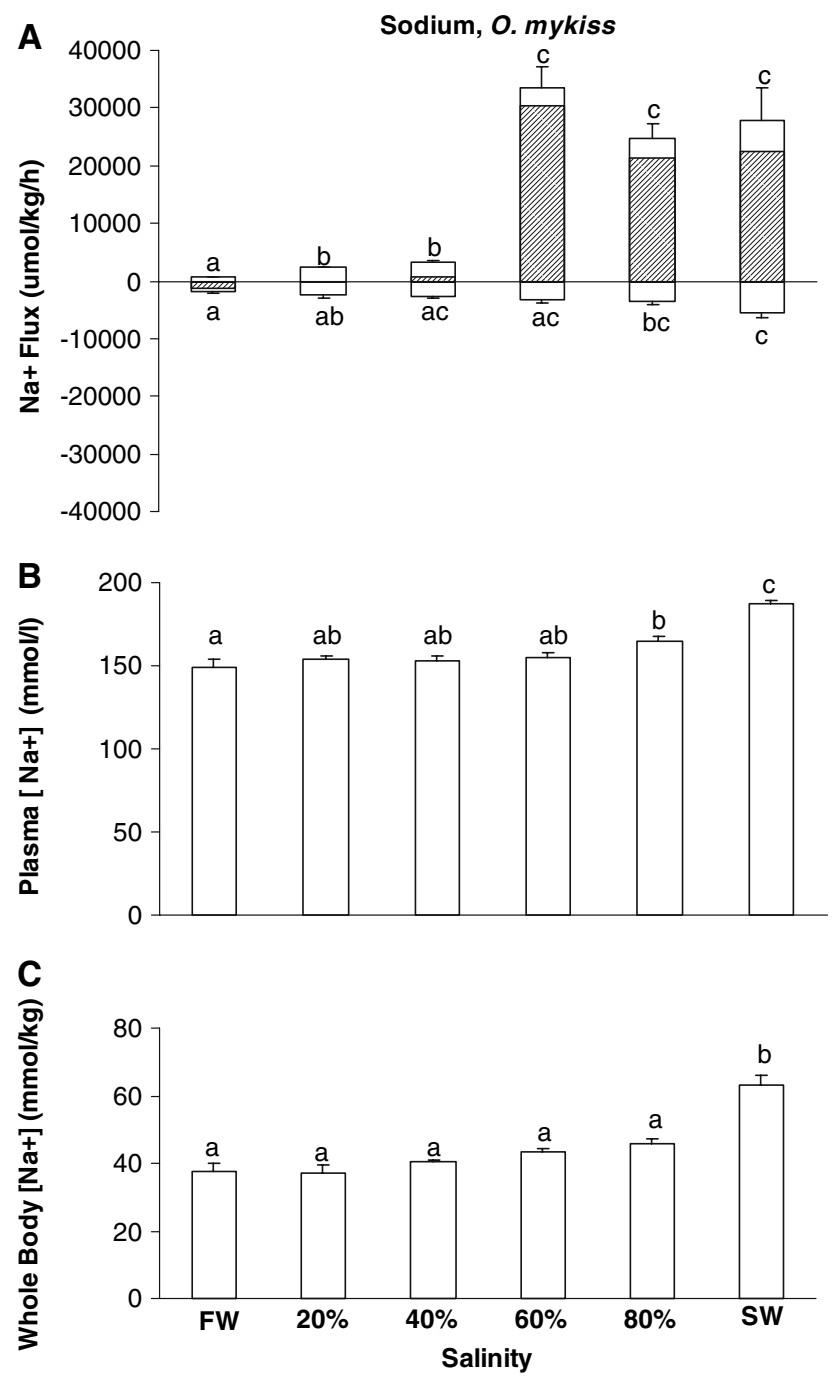

Fig. 2 a $\mathrm{Na}^{+}$influx (upward bars) $(n=6)$ and efflux (downward bars) $(n=6)$ rates (mean $\pm \mathrm{SEM}, \mu \mathrm{mol} / \mathrm{kg} / \mathrm{h})$ in O. mykiss submitted to progressive increases in water salinity over 1 -h periods. The hatched bars represent the difference (net flux rates) between the mean influx (positive) and efflux (negative) rates. b Plasma $\mathrm{Na}^{+}$concentration $(n=6$ for $\mathrm{FW}$ to $80 \% \mathrm{SW}, n=18$ for $100 \%$ $\mathrm{SW})$ (mean $\pm \mathrm{SEM}, \mathrm{mmol} / \mathrm{l})$ in $O$. mykiss submitted to increase in water salinity. $\mathbf{c}$ Whole-body $\mathrm{Na}^{+}$concentration $(n=6$ for $\mathrm{FW}$ to $80 \% \mathrm{SW}, n=12$ for $100 \% \mathrm{SW})($ mean $\pm \mathrm{SEM}, \mathrm{mmol} / \mathrm{kg})$ in O. mykiss submitted to an increase in water salinity. Bars sharing a letter are not significantly different $(P<0.05)$

large increase in influx with increasing salinities, net $\mathrm{Na}^{+}$ flux was highly positive in trout at and above $60 \% \mathrm{SW}$ (Table 2). This led to a significant increase in plasma $\mathrm{Na}^{+}$ (Fig. 2b) and whole body $\mathrm{Na}^{+}$(Fig. 2c) content in the $100 \% \mathrm{SW}$-treated trout, relative to all other salinities.

\section{Unidirectional calcium fluxes}

Unidirectional $\mathrm{Ca}^{2+}$ flux rates in $F$. heteroclitus (Fig. 3a) were much lower than $\mathrm{Na}^{+}$flux rates (Fig. 1a),
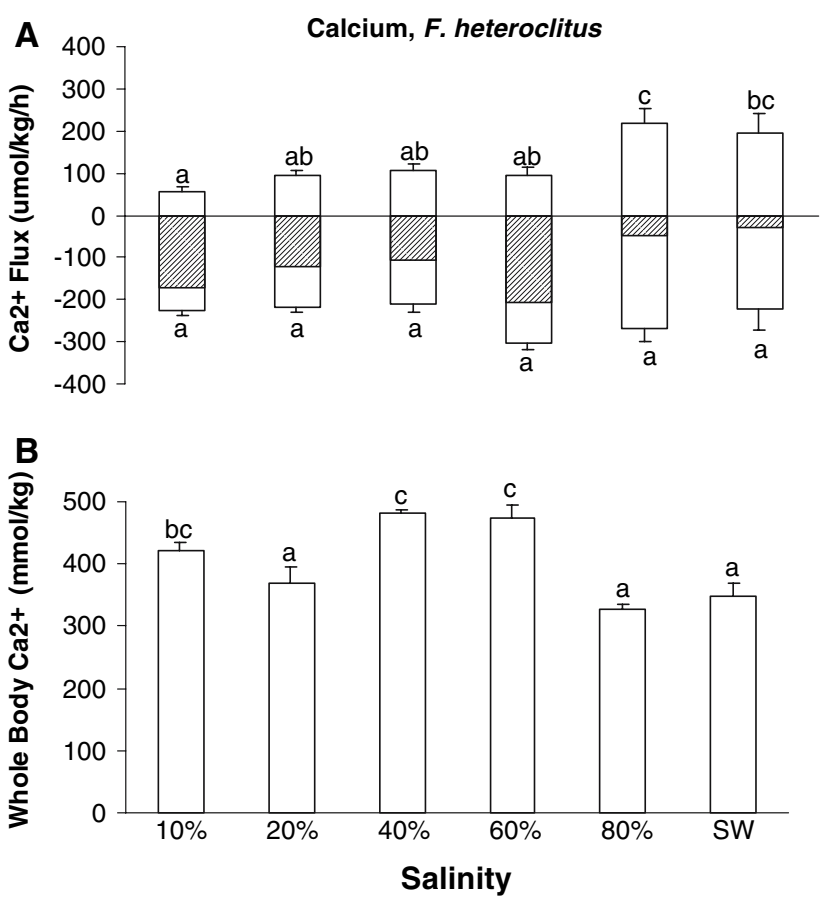

Fig. 3 a Ca ${ }^{2+}$ influx (upward bars) $(n=6)$ and efflux rates (downward bars) $(n=6)$ (mean $\pm \mathrm{SEM}, \mu \mathrm{mol} / \mathrm{kg} / \mathrm{h})$ in $F$. heteroclitus submitted to progressive increases in water salinity over 1 -h periods. The hatched bars represent the difference (net flux rates) between the mean influx (positive) and efflux (negative) rates. b Whole-body $\mathrm{Ca}^{2+}$ concentration $(n=11-13$ for 10,20 , and $100 \% \mathrm{SW}, n=6$ for $40-80 \% \mathrm{SW})($ mean $\pm \mathrm{SEM}, \mathrm{mmol} / \mathrm{kg})$ in $F$. heteroclitus submitted to an increase in water salinity. $S W$ seawater. Bars sharing a letter are not significantly different $(P<0.05)$

and $\mathrm{Ca}^{2+}$ balance was negative at salinities 10,20 and $60 \%$ SW (Table 2). Exposure to 80 and $100 \%$ SW caused at least a two- to threefold increase in $\mathrm{Ca}^{2+}$ influx in F. heteroclitus (to greater than $190 \mu \mathrm{mol} / \mathrm{kg} / \mathrm{h}$ ) compared to those rates measured at the lower salinities (Fig. 3a). In contrast, no significant differences were noted in $\mathrm{Ca}^{2+}$ efflux rates along the entire salinity regime (Fig. 3a). Total body $\mathrm{Ca}^{2+}$ concentration of the killifish was rather variable $(325-480 \mathrm{mmol} / \mathrm{kg})$, but curiously was higher in the intermediate salinities of 40 and $60 \%$ SW than in 20, 80, and $100 \%$ SW (Fig. 3b).

Unidirectional $\mathrm{Ca}^{2+}$ flux rates in O. mykiss (Fig. 4a) were also much lower than $\mathrm{Na}^{+}$flux rates (Fig. 2a), but in contrast to $F$. heteroclitus, $\mathrm{Ca}^{2+}$ balance was always strongly positive at all salinities (Table 2). $\mathrm{Ca}^{2+}$ influx rates had doubled upon exposure to $40 \% \mathrm{SW}$, and rose most dramatically between 80 and $100 \%$ SW (Fig. 4a). Influx in $100 \% \mathrm{SW}$ was about $160 \mu \mathrm{mol} / \mathrm{kg} / \mathrm{h}$ relative to $65 \mu \mathrm{mol} / \mathrm{kg} / \mathrm{h}$ in $80 \% \mathrm{SW}$ and only $22 \mu \mathrm{mol} / \mathrm{kg} / \mathrm{h}$ in FW. $\mathrm{Ca}^{2+}$ efflux rates were always very low $(\sim 5.0 \mu \mathrm{mol} / \mathrm{kg} / \mathrm{h}$, Fig. 4a), and unaltered by salinity. Plasma $\mathrm{Ca}^{2+}$ did not change with increasing salinity up to $80 \%$ SW (Fig. 4b) but increased significantly in $100 \%$ SW (Fig. 4b). 

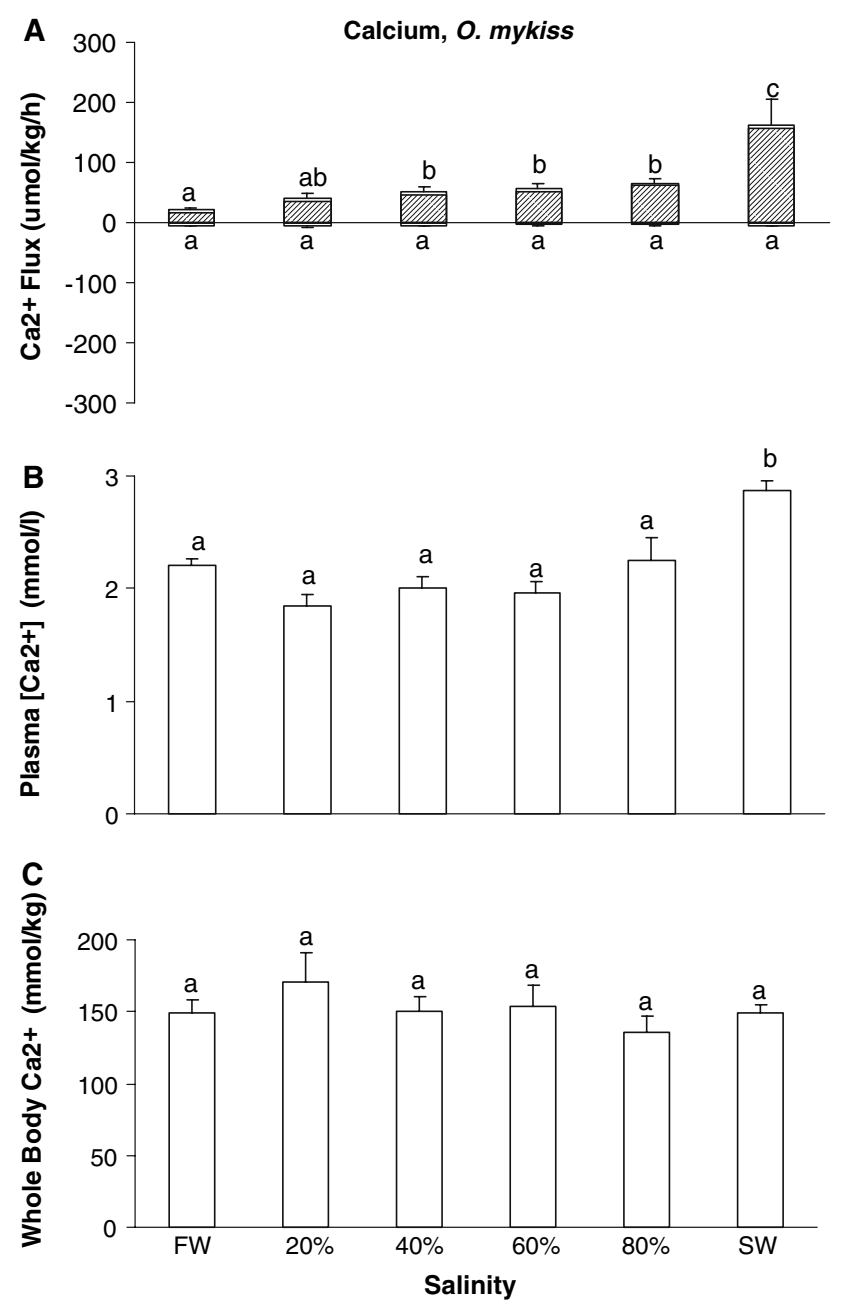

Fig. 4 a $\mathrm{Ca}^{2+}$ influx (upward bars) $(n=6)$ and efflux rates (downward bars) $(n=6)($ mean $\pm \mathrm{SEM}, \mu \mathrm{mol} / \mathrm{kg} / \mathrm{h})$ in $O$. mykiss submitted to progressive increases in water salinity over 1-h periods. The hatched bars represent the difference (net flux rates) between the mean influx (positive) and efflux (negative) rates. b Plasma $\mathrm{Ca}^{2+}$ concentration $(n=6)$ (mean $\left.\pm \mathrm{SEM}, \mathrm{mmol} / \mathrm{l}\right)$ in $O$. mykiss submitted to increase in water salinity. c Whole-body $\mathrm{Ca}^{2+}$ concentration ( $n=6$ for $\mathrm{FW}-80 \%$ SW, $n=12$ for $100 \%$ SW) (mean $\pm \mathrm{SEM}, \mathrm{mmol} / \mathrm{kg}$ ) in $O$. mykiss submitted to an increase in water salinity. $F W$ freshwater, $S W$ seawater. Bars sharing a letter are not significantly different $(P<0.05)$

Whole-body $\mathrm{Ca}^{2+}$ in $O$. mykiss was kept constant, at approximately $150 \mathrm{mmol} / \mathrm{kg}$ (Fig. 4c), less than $50 \%$ of the value in killifish (Fig. 3b).

\section{Discussion}

Although the physiological basis of ion regulation in euryhaline fishes has been well studied (see Introduction for reviews), most experimental protocols have looked only at the responses of these animals to either long-term acclimation or short-term salinity challenges.
This study is unique in that fish were subjected to a salinity regime designed to mimic a tidal flow, taking animals from either freshwater or $10 \%$ SW to full strength SW over a 6 -h period. We provide clear evidence of the differential ability of killifish versus trout to tolerate this acute, progressive salinity increase. Killifish were able to almost maintain net $\mathrm{Na}^{+}$balance, with concomitant changes in influx and efflux of the ion as water salinity was experimentally increased. In comparison, rainbow trout suffered massive increases in $\mathrm{Na}^{+}$influx with only very modest increases in $\mathrm{Na}^{+}$ efflux as the animals transitioned from 40 to $60 \% \mathrm{SW}$. This imbalance persisted at higher salinities which resulted in elevated plasma and whole-body $\mathrm{Na}^{+}$levels in trout taken through to full-strength SW.

Values of $\mathrm{Na}^{+}$unidirectional fluxes measured in the killifish in $10 \%$ SW were similar to those previously determined for this species at a similar salinity (Wood and Laurent 2003). However, at the end of the $6 \mathrm{~h}$ of progressive salinity elevation in $100 \% \mathrm{SW}, \mathrm{Na}^{+}$influx and efflux rates were still in balance and much lower (less than half) than flux rates in $100 \%$ SW $(\sim 20,000$ $40,000 \mu \mathrm{mol} / \mathrm{kg} / \mathrm{h}$ ) determined in previous studies on killifish acclimated to $100 \%$ SW (Motais et al. 1966; Potts and Evans 1967; Pic 1978; Wood and Marshall 1994; Wood and Laurent 2003). Evidently, over the course of a single tidal cycle of incremental salinity rise, killifish are very effective at limiting passive $\mathrm{Na}^{+}$ uptake and therefore do not need to increase active $\mathrm{Na}^{+}$efflux to the same extent as when they are chronically exposed to higher salinities. This is likely an important adaptation that provides significant benefits for dealing with the fluctuation this species normally must cope with.

There is abundant literature demonstrating the physiological adaptations that occur when $F$. heteroclitus are acutely transferred from FW or brackish water to $100 \% \mathrm{SW}$. These include an increase in drinking rate, increased renal loss of $\mathrm{Na}^{+}$and $\mathrm{Cl}^{-}$, and activation of salt secretion through gills and opercular epithelia to counteract increased passive (gills) and active (gut) salt influxes (Potts and Evans 1967; Jacob and Taylor 1983; Wood and Marshall 1994; Jobling 1995; Zadunaisky et al. 1995; Marshall et al. 1999; Marshall 2003; Wood and Laurent 2003). Plasma cortisol rises, leading to fast regulatory changes aided by the autonomic sympathetic system: branchial $\mathrm{Na}^{+}, \mathrm{K}^{+}-$ ATPase activity rapidly increases (Marshall et al. 1999; Mancera and McCormick 2000; Scott et al. 2004), apical crypts of mitochondria-rich cells are further exposed (Daborn et al. 2001), and NKCC is posttranslationally regulated by phosphorylation (Marshall et al. 1999; Marshall 2003). However, it remains to be 
determined which of these adjustments are actually implemented, and the extent to which they occur, during the more natural situation of progressive salinity rise during a tidal cycle. The $\mathrm{Na}^{+}$flux data of the present study suggests that the changes which actually occur may be considerably smaller than that seen with traditional acute transfer protocols. This will be a rich area for future investigation.

In comparison, trout showed markedly different responses to salinity than observed in killifish. Trout experienced a drastic increase in $\mathrm{Na}^{+}$influx at salinities of $60 \% \mathrm{SW}$ and higher, reflecting an increase in passive movement of $\mathrm{Na}^{+}$into the animal, despite a likely down-regulation of active salt absorption (Bath and Eddy 1979a,b; Eddy and Bath 1979; Jobling 1995; Marshall 2002; Evans et al. 2005; Marshall and Grosell 2005). As a result, the trout showed increased plasma and whole-body sodium levels, especially in fullstrength SW. A loss of permeability control, perhaps due to cell shrinkage and associated opening up of tight junctions once external osmolality surpasses internal osmolality (Bath and Eddy 1979b) may have contributed to this problem, and have been compounded by the slow, small response in $\mathrm{Na}^{+}$efflux activation. With regard to the latter, our data are in accord with the report of Bath and Eddy (1979b) on adult rainbow trout that $\mathrm{Na}^{+}$efflux was not activated until $5 \mathrm{~h}$ after transfer to seawater. A very similar result was reported for the Mozambique tilapia Oreochromis mossambicus, a strongly euryhaline freshwater species. When submitted to a comparable protocol of salinity increase over $4 \mathrm{~h}$, tilapia experienced a large net $\mathrm{Na}^{+}$influx at higher salinities (Vonck et al. 1998).

Although killifish and trout showed differential responses in $\mathrm{Ca}^{2+}$ influx to salinity, uptake rates in both species had a propensity to increase with elevations in salinity. Killifish showed a large net secretion of $\mathrm{Ca}^{2+}$ until $60 \% \mathrm{SW}$, with net $\mathrm{Ca}^{2+}$ balance coming closer to zero but still negative at higher salinities when influx increased but efflux did not change. A paradoxical situation was observed, in that, at lower salinities, there is significant net efflux of calcium, but a rise in wholebody calcium levels; with further increase in salinity, influx increases, net secretion of calcium decreases, but surprisingly, whole-body calcium displays lower values. The explanation is likely random variation in the whole body calcium concentrations among treatment groups. It should be pointed out that whole body calcium concentrations are very high in killifish, around $400 \mathrm{mmol} / \mathrm{kg}$ or two- to threefold higher than in trout (Fig. 3b vs. Fig. 4c). By way of contrast, the net calcium fluxes in killifish are less than $200 \mu \mathrm{mol} / \mathrm{kg} / \mathrm{h}$ (Fig. 3a) and thus would have exerted negligible impact on whole body calcium concentrations in the few hours duration of these experiments. Normally, these fish may utilize the diet to achieve whole body calcium balance, just as they do for $\mathrm{Cl}^{-}$balance in fresh water (Wood and Marshall 1994; Wood and Laurent 2003). It is likely that gill fluxes serve to regulate only the fast exchangeable portion of the calcium pool (extracellular calcium), and that the bulk of whole body calcium is sequestered in slowly exchanging pools such as bone and scale, which respond mainly to dietary calcium availability.

Previous data obtained from the killifish in fresh water have revealed low values of $\mathrm{Ca}^{2+}$ influx $(10-70 \mu \mathrm{mol} / \mathrm{kg} / \mathrm{h})$ (Mayer-Gostan et al. 1983). The current study yielded values in the upper part of this range at the lowest salinity $(10 \% \mathrm{SW})$, but higher influx values (up to $190 \mu \mathrm{mol} / \mathrm{kg} / \mathrm{h}$ in $100 \% \mathrm{SW}$ ) at elevated salinities, presumably due to the higher $\mathrm{Ca}^{2+}$ concentration of the saline waters compared to the fresh water. In fresh water, the isolated opercular epithelia and gills of the killifish are known to be sites of net $\mathrm{Ca}^{2+}$ uptake (Mayer-Gostan et al. 1983; Marshall et al. 1995; Verbost et al. 1997; Patrick et al. 1997). Verbost et al (1997) reported lower rates of $\mathrm{Ca}^{2+}$ uptake in isolated opercular epithelia from seawater-acclimated killifish, but the situation in vivo may be different. The site(s) of the rather large effluxes of $\mathrm{Ca}^{2+}$ in all salinities are unknown. As for $\mathrm{Na}^{+}$, more studies are needed to understand the physiological regulation of $\mathrm{Ca}^{2+}$ homeostasis in euryhaline teleosts in the progressively changing salinities typical of estuaries.

In contrast to killifish, trout exhibited a net absorption of $\mathrm{Ca}^{2+}$ at all salinities, as influx greatly exceeded efflux, especially in $100 \% \mathrm{SW}$, which resulted in a significant rise in plasma calcium levels. Indeed, $\mathrm{Ca}^{2+}$ efflux rate remained invariant and very low at all salinities. $\mathrm{Ca}^{2+}$ influx rates were also quite low in freshwateracclimated trout, in accord with previous reports (Perry and Wood 1985; Perry and Flik 1988), but increased with salinity, and became particularly large in $100 \% \mathrm{SW}$. The same pattern has also been observed in Mozambique tilapia $O$. mossambicus. In fresh water, unidirectional fluxes of $\mathrm{Ca}^{2+}$ in tilapia (Flik et al. 1985, Vonck et al. 1998) were very similar to those measured in trout, and showed a similar trend of increase with environmental salinity. It is unclear whether this effect is mediated by the elevated salinity, or instead is a reflection of the concomitant increase in external $\mathrm{Ca}^{2+}$ (Perry and Wood 1985; Flik et al. 1986; Vonck et al. 1998; Marshall 2002). By analogy to tilapia, the greatly increased rates of $\mathrm{Ca}^{2+}$ uptake in trout submitted to salinity increase may be partially explained by the increased activity of the branchial basolateral $\mathrm{Na}^{+} / \mathrm{Ca}^{2+}$ exchanger (Verbost et al. 1994). It is doubtful that such 
large $\mathrm{Ca}^{2+}$ net loading at high salinity is of adaptive significance; as with $\mathrm{Na}^{+}$balance, it more likely reflects a pathological rather than a beneficial response to progressive salinity increase in the rainbow trout. Again, the adaptive ability of the rainbow trout with respect to salinity increase appears to be inferior to that of the killifish.

To conclude, this study has shown that the estuarine killifish, when faced with an incremental rise in salinity, is able to limit $\mathrm{Na}^{+}$influx to tolerable levels and compensate by raising its rate of $\mathrm{Na}^{+}$efflux to maintain approximate $\mathrm{Na}^{+}$balance, probably mediated by a rise in extracellular osmolality (not measured here) (Marshall et al. 1999, 2000; Marshall 2003). This result is entirely compatible with the ability of this species to endure fast salinity increases in its natural habitat on a daily basis. The killifish strongly secretes $\mathrm{Ca}^{2+}$, even in relatively low salinities. In contrast, the freshwater rainbow trout, although able to tolerate salinities approaching full-strength SW after long-term gradual acclimation, cannot cope once salinities of about $60 \%$ or higher are reached during a progressive salinity increase over $6 \mathrm{~h}$ typical of a tidal cycle. $\mathrm{Na}^{+}$and $\mathrm{Ca}^{2+}$ influx rates rise drastically, while there is little compensating rise in efflux rates. The ability to maintain both $\mathrm{Na}^{+}$and $\mathrm{Ca}^{2+}$ homeostasis is lost. This result is entirely compatible with the fact that this species does not normally face such salinity stress in its natural habitat.

Acknowledgments Supported by an NSERC (Canada) Discovery grant to CMW. We thank Dr. W.S. Marshall for his help in obtaining killifish. The authors gratefully acknowledge the financial support from CAPES (Graduate Studies Sponsor, Brazilian Government) through a travel award and fellowship received by $\mathrm{VP}$, allowing her to conduct these experiments in the laboratory of CMW in McMaster University, Hamilton, Canada. CMW is supported by the Canada Research Chair Program.

\section{References}

Barnes HJ (1954) Ionic composition of seawater. J Exp Biol 31:582-588

Bath RN, Eddy FB (1979a) Salt and water balance in rainbow trout (Salmo gairdneri) rapidly transferred from fresh water to sea water. J Exp Biol 83:193-202

Bath RN, Eddy FB (1979b) Ionic and respiratory regulation in rainbow trout during rapid transfer to seawater. J Comp Physiol B 134:351-357

Daborn K, Cozzi RRF, Marshall WS (2001) Dynamics of pavement cell-chloride cell interactions during abrupt salinity change in Fundulus heteroclitus. J Exp Biol 204:1889-1899

Eddy FB, Bath RN (1979) Ionic regulation in rainbow trout (Salmo gairdneri) adapted to fresh water and dilute sea water. J Exp Biol 83:181-192

Evans DH, Piermarini PM, Potts WTW (1999) Ionic transport in the fish gill epithelium. J Exp Zool 283:641-652
Evans DH, Piermarini PM, Choe KP (2005) The multifunctional fish gill: dominant site of gas exchange, osmoregulation, acidbase regulation, and excretion of nitrogenous waste. Physiol Rev 85:97-177

Flik G, Fenwick JC, Kolar Z, Mayer-Gostan N, Wendelaar Bonga SE (1985) Whole-body $\mathrm{Ca}^{2+}$ flux rates in cichlid teleost fish Oreochromis mossambicus adapted to freshwater. Am J Physiol 249:R432-R437

Flik G, Fenwick JC, Kolar Z, Mayer-Gostan N, Wendelaar Bonga SE (1986) Effects of low ambient calcium levels on the whole-body $\mathrm{Ca}^{2+}$ flux rates and internal calcium pools in the freshwater cichlid teleost, Oreochromis mossambicus. J Exp Biol 120:249-264

Gordon MS (1959) Ionic regulation in the brown trout (Salmo trutta L.). J Exp Biol 36:227-252

Gordon MS (1963) Chloride exchanges in rainbow trout (Salmo gairdneri) adapted to different salinities. Biol Bull 124:45-54

Goss GG, Perry SF, Fryer JN, Laurent P (1998) Gill morphology and acid-base regulation in freshwater fishes. Comp Biochem Physiol A 119:107-115

Griffith RW (1974) Environment and salinity tolerance in the genus Fundulus. Copeia 1974:319-331

Hawkings GS, Galvez F, Goss GG (2004) Seawater acclimation causes independent alterations in $\mathrm{Na}^{+} / \mathrm{K}^{+}$- and $\mathrm{H}^{+}$-ATPase activity in isolated mitochondria-rich cell subtypes of the rainbow trout gill. J Exp Biol 207:905-912

Jacob WF, Taylor MH (1983) The time course of seawater acclimation in Fundulus heteroclitus L. J Exp Zool 228:33-39

Jobling M (1995) Environmental biology of fishes. Chapman and Hall, London

Katoh F, Hyodo S, Kaneko T (2003) Vacuolar-type proton pump in the basolateral plasma membrane energizes ion uptake in branchial mitochondria-rich cells of killifish Fundulus heteroclitus, adapted to a low ion environment. J Exp Biol 206:793-803

Kirschner LB (2004) The mechanism of sodium chloride uptake in hyperregulating aquatic animals. J Exp Biol 207:14391452

L'Annunziata MF (2003) The handbook of radioactivity analysis, 2nd edn. Academic Press, New York

Mancera JM, McCormick SD (2000) Rapid activation of gill $\mathrm{Na}^{+}, \mathrm{K}^{+}$-ATPase in the euryhaline teleost Fundulus heteroclitus. J Exp Zool 287:263-274

Marshall WS (2002) $\mathrm{Na}^{+}, \mathrm{Cl}^{-}, \mathrm{Ca}^{2+}$ and $\mathrm{Zn}^{2+}$ transport by fish gills: retrospective review and prospective synthesis. J Exp Zool 293:264-283

Marshall WS (2003) Rapid regulation of $\mathrm{NaCl}$ secretion by estuarine teleost fish: coping strategies for short-duration freshwater exposures. Biochim Biophys Acta 1618:95-105

Marshall WS, Grosell M (2005) Ion transport, osmoregulation, and acid-base balance. In: Evans DH, Claiborne JB (eds) Physiology of fishes. CRC Press, Boca Raton, pp 177-230

Marshall WS, Bryson SE, Burghardt JS, Verbost PM (1995) $\mathrm{Ca}^{2+}$ transport by opercular epithelium of the fresh water adapted euryhaline teleost, Fundulus heteroclitus. J Comp Physiol B 165:268-277

Marshall WS, Emberley TR, Singer TD, Bryson SE, McCormick SD (1999) Time course of salinity adaptation in a strongly euryhaline estuarine teleost, Fundulus heteroclitus: a multivariable approach. J Exp Biol 202:1535-1544

Marshall WS, Bryson SE, Luby T (2000) Control of epithelial $\mathrm{Cl}^{-}$ secretion by basolateral osmolality in the euryhaline teleost Fundulus heteroclitus. J Exp Biol 203:1897-1905

Mayer-Gostan N, Bornancin M, DeRenzeis G, Naon R, Yee JA, Shew RL, Pang PKT (1983) Extraintestinal calcium uptake in the killifish, Fundulus heteroclitus. J Exp Zool 227:329-338 
Motais R, Garcia-Romeu F, Maetz J (1966) Exchange diffusion effect and euryhalinity in teleosts. J Gen Physiol 50:391-442

Patrick ML, Wood CM, Marshall WS (1997) Calcium regulation in the freshwater-adapted mummichog. J Fish Biol 51:135145

Perry SF, Flik G (1988) Characterization of branchial transepithelial calcium fluxes in freshwater trout, Salmo gairdneri. Am J Physiol 254:R491-R498

Perry SF, Laurent P (1989) Adaptational responses of rainbow trout to lowered external $\mathrm{NaCl}$ concentrations: contribution of the branchial chloride cell. J Exp Biol 147:147-168

Perry SF, Wood CM (1985). Kinetics of branchial calcium uptake in the rainbow trout: effects of acclimation to various external calcium levels. J Exp Biol 116:411-433

Pic P (1978) A comparative study of the mechanism of $\mathrm{Na}^{+}$and $\mathrm{Cl}^{-}$excretion by the gill of Mugil capito and Fundulus heteroclitus: effects of stress. J Comp Physiol 123:155-162

Potts WTW, Evans DH (1967) Sodium and chloride balance in the killifish Fundulus heteroclitus. Biol Bull 133:411-425

Richards JG, Semple JW, Bystriansky JS, Schulte PM (2003) $\mathrm{Na}^{+} /$ $\mathrm{K}^{+}$-ATPase $\alpha$-isoform switching in gills of rainbow trout (Oncorhynchus mykiss) during salinity transfer. J Exp Biol 206:4475-4486

Scott GR, Rogers JT, Richards JG, Wood CM, Schulte PM (2004) Intraspecific divergence of ionoregulatory physiology in the euryhaline teleost Fundulus heteroclitus: possible mechanisms of freshwater adaptation. J Exp Biol 207:3399_ 3410
Sedgewick SD (1982) The Salmon handbook. The life and cultivation of fishes of the Salmon family. Andre Deutsch Ltd., London, p 242

Verbost PM, Schoenmakers THJM, Flik G, Wendelaar Bonga SE (1994) Kinetics of ATP- and $\mathrm{Na}^{+}$-gradient driven $\mathrm{Ca}^{2+}$ transport in basolateral membranes from gills of freshwater and seawater-adapted tilapia. J Exp Biol 186:95-108

Verbost PM, Bryson SE, Wendelaar Bonga SE, Marshall WS (1997) $\mathrm{Na}^{+}$-dependent $\mathrm{Ca}^{2+}$ uptake in isolated opercular epithelium of Fundulus heteroclitus. J Comp Physiol B 167:205-212

Vonck APMA, Wendelaar Bonga SE, Flik G (1998) Sodium and calcium balance in Mozambique tilapia, Oreochromis mossambicus, raised at different salinities. Comp Biochem Physiol A 119:441-449

Wolf K (1963) Physiological salines for freshwater teleosts. Prog Fish Cult 25:135-140

Wood CM, Laurent P (2003) $\mathrm{Na}^{+}$versus $\mathrm{Cl}^{-}$transport in the "killifish" after rapid salinity transfer. Biochim Biophys Acta 1618:106-119

Wood CM, Marshall WS (1994) Ion balance, acid-base regulation, and chloride cell function in the common killifish, Fundulus heteroclitus - a euryhaline estuarine teleost. Estuaries 17:34-52

Zadunaisky JA, Cardona S, Au L, Roberts DM, Fisher E, Lowenstein B, Cragoe EJ Jr (1995) Chloride transport activation by osmolarity during rapid adaptation to high salinity of Fundulus heteroclitus. J Membr Biol 143:207-217 